\title{
THE LEVEL OF STUDENTS' ENGAGEMENT IN ARABIC WITHIN PUBLIC UNIVERSITIES
}

\section{Lily Hanefarezan Asbulah ${ }^{1,4 *}$, Maimun Aqsha Lubis ${ }^{1}$, Ashinida Aladdin² and Mus'ab Sahrim ${ }^{3}$}

\author{
${ }^{1}$ Faculty of Education, Universiti Kebangsaan Malaysia, 43600 \\ UKM Bangi, Selangor, Malaysia \\ ${ }^{2}$ School of Languages and Linguistic, Faculty of Social Sciences and Humanities, \\ Universiti Kebangsaan Malaysia, 43600 UKM Bangi, Selangor, Malaysia \\ ${ }^{3}$ Faculty of Engineering and Built Environment, Universiti Sains Islam Malaysia, \\ 71800 Nilai, Negeri Sembilan, Malaysia \\ ${ }^{4}$ Faculty of Languages and Linguistics, University of Malaya, \\ 50603 Kuala Lumpur, Malaysia \\ *Corresponding author: lilyhane@um.edu.my
}

Publication date: 30 June 2020

To cite this article: Lily Hanefarezan Asbulah, Maimun Aqsha Lubis, Ashinida Aladdin and Mus'ab Sahrim. (2020). The level of students' engagement in Arabic within public universities. Asia Pacific Journal of Educators and Education, 35(1), 1-16. https://doi. org/10.21315/apjee2020.35.1.1

To link to this article: https://doi.org/10.21315/apjee2020.35.1.1

\begin{abstract}
The aim of this study is to measure the level of engagement among the Arabic students' of public universities. As such, two engagement dimensions were analysed: (a) inside the classroom and (b) outside the classroom. In this study, a total of 344 Arabic students were employed as respondents due to the nature of the study, which is crosssectional involving final year Arabic students from eight public universities. In order to achieve the aim of this study, a simple random sampling method was used in line with the sampling frame. IBM SPSS version 19.0 was used to analyse the data of this study descriptively, such as the mean, standard deviation, and percentage respectively. The findings showed that the engagement of graduates to study the Arabic in the classroom is at moderate level, and followed by lower level outside the classroom. Overall, it was discovered that the engagement of Arabic students at the Malaysian public university level is still moderate and as such the authorities need to take initiative to improve this situation. Thus, the students have to maximise their engagement inside the classroom and outside the classroom at the university. This is assumed to indirectly contribute to higher achievement in the Arabic as well as to produce competent Arabic graduates.
\end{abstract}

Keywords: Engagement, inside classroom, outside classroom, Arabic, public universities

(C) Penerbit Universiti Sains Malaysia, 2020. This work is licensed under the terms of the Creative Commons Attribution (CC BY) (http://creativecommons.org/licenses/by/4.0/). 


\section{INTRODUCTION}

The environment has been seen as an important element in improving the student's learning development. As stated by Keefe (1991), a good language environment will stimulate the development of better learning. This is because the environment is one of the pre-requisites in learning a second language (Maimun, 1997). Additionally, learning the Arabic and its usage is assumed to form language activity among the students. Hence, it is important to create an Arabic environment within certain parties who are assisting in the teaching and learning of the language. Spontaneously, the Arabic environment that is created from the language activity has been seen to happen on daily basis, whether from inside or outside the formal or informal place of study.

There are previous scholars who have discussed the factors that led to the learning of a second language, where they suggested that in order to create a positive environment for Arabic learning, space and opportunity should be made available so as to enhance the students Arabic proficiency. This coincides with Littlewood's (1981) view, which took into account the classroom's social environment to be used as an artificial environment (classroom as a social context). As such, Littlewood suggested four approaches in reviving the artificial environment, which include; (a) using foreign language completely in classroom management, (b) using foreign language in teaching, (c) using foreign language in discussion sessions, and (d) employing dialogue to share the experiences or problems encountered by students using foreign language. Other scholars suggested that cheerful environment can also bring fun and enthusiasm for students to learn (Norhayati, Shaferul Hafes, \& Mohd Fauzi, 2013).

According to Zawawi (2001), the environment also provides greater and wider opportunities for Arabic learners in using the language, where he further categorised the language environment into lectures, campuses, social and cocurricular activities. Among other activities that enable Arabic environments to be alive are: Lecture should be conducted fully in Arabic, students should communicate using Arabic among themselves, students should ask questions using Arabic inside or outside the classroom, read the Arabic signage, listen to Arabic radio, listen to Arabic song, read Arabic newspaper, browse Arabic websites, and attend Arabic language society activities. All these are supported by the findings of previous studies which identified reading activities, watching television and movies (Schmitt \& Redwood, 2011), speaking with native Arabic speakers, and social media usage (Fernandez \& Schmitt, 2015) to have significant relationships in enhancing the mastery of language learning. 
However, the environment is not sufficient to make someone learn the collocation perfectly. As such, one requires the element of interest and determination that comes from within in order to do the activity (Philp \& Duchesne, 2016). This is because, as stated by Ellis (2005), and Fernandez and Schmitt (2015), the quantity of language environment exposure does not determine one goal of acquiring a language proficiency, but to what extent the quality of students' engagements with such language in their daily lives. Hence, the question is how far the Arabic students really maximise their engagement in the language throughout their university lives. Thus, this study is aimed to investigate the level of students engagement in Arabic in their current daily situation at the university level, which could be either during class or outside classroom.

\section{ENGAGEMENT INSIDE AND OUTSIDE CLASSROOM}

Engagement is an overly broad spectrum to be discussed in this study. Available literatures show that among the characters in the words which describe "engagement" in the English language are engaged, effort, interest, focus, determination and persistence, which are all seen as signs of durability (Skinner \& Pitzer, 2012). Additionally, Kuh (2009) defined engagement as the quality of engagement and effort of students in the learning process at the institutions of higher learning. Therefore, engagement is a more accurate word to describe students who are actively employing the daily use of Arabic, either through activities, media and social interaction at university level. This engagement covers the scope of classroom and outside, which could be formal, informal, organised or otherwise (Brown, 1994).

Also, classrooms are often associated with artificial environments, particularly in the process of learning and usage of foreign languages. On the other hand, being outside classroom which includes the campus environment helps the students to gain more information about the languages through listening or even in writing. Various activities and programs are organised by students or administrators in university environment to encourage students to participate in language learning.

In addition, the mass media also plays a very important role and influence in the era of globalisation today. This is because, the media has been said to have its own contributions and attractions in language learning (Zawawi, 2001). As such, Sohana (2016) referred to it as the channel used to convey information. Currently, there are two types of mass media; print and electronic media. The former comprises newspapers, magazines, books and so on, while the latter consists of television, 
radio and internet. According to Kamus Dewan, the word "media" refers to a medium of communication (Noresah, 2005), comprising electronic and print media in conveying information to readers. However, the text-based print media (writing) has been identified to have a close relation in the life of a university student.

Additionally, electronic media (computer and internet) also play an important role in learning second language or foreign language nowadays. This is because the internet offers broad and rich learning resources in providing input in terms of authentic language, through the use of the smartphones that provide convenience to users. As such, smartphones have been categorised to be capable of operating like a computer. The reason is that, many activities can be carried out through it, such as communication, information sharing, and internet browsing (Al-Barashdi, Buoazza, \& Jabur, 2015). Currently, the frequently used media networks by institute of higher learning's students are WhatsApp, Telegram and WeChat, while the most popular social media website is Facebook (Fariza, Md Yusoff, \& Mohd Khalid, 2016).

Available literatures showed that the use of technology, such as computers and internet as a teaching aid (ABM) will help increase the engagement of students in learning foreign languages (Chen, Lambert, \& Guidry, 2010). Other than that, technology is being used as an important medium in teaching and learning in higher education institution, especially in Arabic (Ahmad Zaki, Ahmed Thalal, Ahmad Abdul Rahman, Nor Abdul Rahman, \& Mohd Shahriman, 2017). Among previous studies that have shown the use of computer in aiding language learning, hence making it a positive impact in Arabic learning are the studies of Ahmad Zaki et al. (2017), Mohd Firdaus (2012), and Mohd Firdaus, Muhammad Sabri and Mohd Shahrizal (2013).

In the social setting, interactions can be said to be the root of dimensions of engagement. Furthermore, social interaction has been seen as the use of language in situations that require its real usage. Hence, the real situation in everyday usage of language can be transferred into lectures. As such, the lecturers can make classroom teaching as a social environment field by using the target language as the real situation completely, without making any translation (Littlewood, 1981). This concept was reinforced by Tu'aymah (2004), when the situation in the classroom was made to resemble the training grounds, where swimming pool was used as a preparation place before sailing in the open sea. Allwright (1984) argued that practicing communication in the classroom is very useful for students in enabling them to apply the language they learn outside the classroom. In this context, the communication means talking activities between fellow lecturers and students while they exchange the role of speakers and listeners. 
Also, listening skills has been seen to be used and developed during interactions between student versus lecturers and students versus students. Rost (2002) classified listening skills to three types; intensive, selective and interactive listening skills. The intensive listening skills involve certain sounds, such as words and phrases that are commonly used in teaching techniques for dictation skills (imla'). While the selective listening skills are seen as the skill use in obtaining certain information that has been determined from the audio material. The interactive listening skills on the other hand, are skill in the forms of conversations and interactions that emphasise on the acquisition of meaning from the conversation. This type of listening skill is utilised during interactions between lecturers versus students and students versus students, which could be either in social situations in the classroom or outside the classroom.

Engagement in this study refers to the extent to which students communicate with Arabic in their everyday activities. It covers all language activities that occur in the classroom or outside the classroom, which could be formal or informal, planned or otherwise (Brown, 1994). As stated by Zawawi (2001), the learning environment needs to be seen as the teaching aspects of classrooms, learning institutions, social environments and co-curricular activities. However, in this study, engagement is defined as the active involvement of students with the use of Arabic in their current daily situation at the university level, which could be either during class or outside classroom, including; (a) media, (b) social and (c) activities.

\section{METHODOLOGY}

This study is a quantitative study which is based on cross-sectional survey. As such, a simple random sampling method was employed using true random generator. A total of 344 final year Arabic students from eight public universities; Universiti Kebangsaan Malaysia (UKM), Universiti Teknologi MARA (UiTM), Universiti Islam Antarabangsa (UIAM), Universiti Sains Islam Malaysia (USIM), Universiti Malaya (UM), Universiti Putra Malaysia (UPM), Universiti Perguruan Sultan Idris (UPSI) and Universiti Sultan Zainal Abidin (UNiSZA); were selected as respondents. This method was selected due to the sampling framework used in this study. Furthermore, the IBM SPSS version 19.0 software was used through descriptive analysis or referred to as the statistic of descent, in order to describe the characteristics of the variables using the mean, standard deviation, frequency, percentage and then making the conclusions based on numerical data (Ghazali \& Sufean, 2016). Based on the data obtained from the questionnaire, this study used 
the mean score as determined by Oxford (1990), which is 1.0 to 2.4 as lower levels, 2.5 and 3.4 as moderate level and 3.5 to 5.0 as high level respectively.

The engagement dimension consists of two sub-dimensions which are inside and outside classroom. The questionnaire items were adopted based on the instrument of Zawawi (2001) and supported by other statements (Al-Hasyimi, 2011; Fernandez \& Schmitt, 2015; Kamarulzaman, Zawawi, \& Nik Mohd Rahimi, 2001; Madkur, 1987; Muhammad Saiful Anuar, Muhammad Luqman, Shahrizal, \& Zawiah, 2017; Rost, 2002). Modifications were subsequently made to the items of the questionnaires chosen in this study. The changes were made to correspond to the terms used in the context of learning Arabic in institutions of higher learning. Each sub-dimensions in classroom and outside classroom measure social elements, media and activities. Social aspects in the classroom and outside classroom were used to measure the engagement of students in social interaction with their colleagues and Arabic lecturers during lectures. While the internal and external media aspects refer to the engagement of students on the use of print or electronic media to obtain learning information. Activities during lecture are referred as the engagement of students in the learning activities or assignments set by the lecturers during the course of their study. While outside classroom activities refer to organised activities performed by certain parties who have the authority, such as students and administrators. In order to illustrate how often students are engaged with the Arabic, the following scales were used, such as $1=$ not very often (never do), 2 = not frequent (doing once or twice), 3 = quite often (doing sometimes), $4=$ often (often doing and not doing once or twice) and $5=$ very often (consistently doing).

\section{FINDINGS}

The results shows that the overall mean of the items engagement is 2.60 and the standard deviation is 0.96 , depicting a moderate level of interpretation. This means that the engagement of students at public universities level in Arabic is moderate even though they are in their final year of study. This finding also shows that there are three items in the high interpretation level, representing $16 \%$ of the total engagement items, six items (32\%) at moderate level, while 10 items (52\%) are found to be at the low level, and the mean range is between 2.03 and 3.73.

For discussion purposes, this study finding is based on sub-dimensions of engagement (classroom and outside classroom). Table 1 shows the frequency, percentage, mean and standard deviation indicators on a decreasing order for 
sub-dimensions in lectures. The result of this analysis shows that there are two items that are in high interpretation, three items in medium interpretation and four items in low interpretation. The items in high interpretation are; "I hear my lecturer speaking fully in Arabic everyday" $(\mathrm{M}=3.73, \mathrm{SD}=1.04)$ and item "I read the Arabic presentation slide shown by my lecturer" $(\mathrm{M}=3.70, \mathrm{SD}=1.00) .(\mathrm{M}=3.31$, $\mathrm{SD}=1.07)$. Meanwhile three items were in moderate interpretation: "I present fully in Arabic in front of the class" $(\mathrm{M}=3.34, \mathrm{SD}=1.17)$, "I search for information in Arabic in the internet" $(\mathrm{M}=3.31, \mathrm{SD}=1.07)$, and "I ask questions in Arabic to my lecturers" $(\mathrm{M}=2.65, \mathrm{SD}=1.05)$. There are four items with low interpretation, which are; "I hear my classmates converse in Arabic" $(\mathrm{M}=2.34, \mathrm{SD}=0.85)$, "I have group discussion in Arabic" $(\mathrm{M}=2.32,0.90)$, "I read journal articles in Arabic" $(\mathrm{M}=2.30, \mathrm{SD}=0.87)$, and "I speak Arabic during class" ( $\mathrm{M}=2.13, \mathrm{SD}=0.70)$.

Table 1. Mean, standard deviation and engagement interpretation during class

\begin{tabular}{llll}
\hline Type of engagement & Mean & SD & Interpretation \\
\hline I hear my lecturer speaking fully in Arabic everyday & 3.73 & 1.04 & High \\
I read the Arabic presentation slide shown by my lecturer & 3.70 & 1.00 & High \\
I present fully in Arabic in front of the class & 3.34 & 1.17 & Moderate \\
I search for information in Arabic in the internet & 3.31 & 1.07 & Moderate \\
I ask question in Arabic to my lecturer & 2.65 & 1.05 & Moderate \\
I hear my classmates converse in Arabic & 2.34 & 0.85 & Low \\
I have group discussion in Arabic & 2.32 & 0.90 & Low \\
I read journal articles in Arabic & 2.30 & 0.87 & Low \\
I speak Arabic during class & 2.13 & 0.70 & Low \\
\hline
\end{tabular}

This finding suggests that in college, students tend to apply only listening and reading skills from social aspects, such as with lecturers. This means that students only depend on the role of lecturers and materials given to them in the classroom. These popular items in learning show that students only need to focus in lectures.

Table 2 on the other hand, shows the frequency, percentage, mean and standard deviation of engagement outside of the classroom in a descending order. The results show that only one item (10\%) received high interpretation, while three items $(30 \%)$ received moderate interpretation, and six items $(60 \%)$ obtained low interpretation. The item with high interpretation is "I speak Arabic with my friends" ( $\mathrm{M}=3.73, \mathrm{SD}=1.04)$. While item with moderate interpretation are; "I attend Arabic activity organised by Arabic society" $(\mathrm{M}=2.98, \mathrm{SD}=1.17)$, "I read Arabic books" (M=2.54, $\mathrm{SD}=1.00)$ and "I watch Arabic videos" $(\mathrm{M}=2.49$, 
$\mathrm{SD}=1.00)$. This is followed by six items which obtained low interpretation: "I read Arabic advertisement" $(\mathrm{M}=2.41, \mathrm{SD}=0.92)$, "I read the Arabic signage" $(\mathrm{M}=2.37, \mathrm{SD}=0.92)$, "I speak Arabic with native Arabic speakers" $(\mathrm{M}=2.08$, $\mathrm{SD}=0.97)$, "I listen to Arabic radio broadcast" $(\mathrm{M}=2.03, \mathrm{SD}=0.81)$, and "I speak Arabic with lecturers" $(\mathrm{M}=1.92, \mathrm{SD}=0.99)$.

This finding suggests that students prefer to communicate with colleagues outside classroom in Arabic. Therefore, they are more comfortable in practicing Arabic they learn from their colleagues than from lecturers and native Arabic speakers (Arabian) outside the classroom. As such, one can say that this situation is caused by a sense of inferiority, shyness and fear that there might be mistakes in their Arabic if they interact with lecturers and outsiders from Arabic speaking countries compared with their friends. Thus, their engagement with friends in learning should be seen as positive and encouraging as friends are considered as learning models to other friends (Ghazali, Nik Mohd Rahimi, Parilah, Wan Haslina, \& Muhammad Sabri, 2012).

Table 2. Mean, standard deviation and engagement interpretation outside class

\begin{tabular}{llll}
\hline Type of engagement & Mean & SD & Interpretation \\
\hline I speak Arabic with my friends & 3.73 & 1.04 & High \\
I attend activities organised by Arabic association & 2.98 & 1.17 & Moderate \\
I read Arabic books & 2.54 & 1.00 & Moderate \\
I watch Arabic videos & 2.49 & 1.00 & Moderate \\
I read Arabic advertisements & 2.41 & 0.92 & Low \\
I read Arabic signage & 2.37 & 0.92 & Low \\
I participate in Arabic competitions & 2.26 & 1.05 & Low \\
I speak Arabic with native Arabic speakers (Arab people) & 2.08 & 0.97 & Low \\
I listen to Arabic radio broadcast & 2.03 & 0.81 & Low \\
I speak Arabic with lecturers & 1.92 & 0.99 & Low \\
\hline
\end{tabular}

\section{DISCUSSION}

Overall, this study findings show that public universities students' level of Arabic engagement is at a moderate level. This is evidenced by the fact that the degree of engagement during class is at a moderate level while the engagement outside the classroom is low. However, each sub-engagement shows different levels of engagements. In-depth discussion is as follows: 


\section{During Class}

Students are seen as to be more inclined to use listening and reading skills in lectures, such as listening to what their lecturers are saying and reading presentation slides prepared by their lecturers. According to Brown (2000), teachers are said to be the main input sources in the learning process. The simple and concise use of lughatul fasl among instructors is said to be one of the practical ways in Arabic teaching and learning (Izuddin, 2008). However, issues arise when students depend so much on teachers, leading to their silence during the learning period (Richards \& Rodgers, 2001). This means that students are only dependent on the role of teachers and materials given in the classroom. Rosni (2011) also acknowledged that students in Arabic studies at university level are still influenced by lecturer-centred learning. On the other hand, this shows that lecturers play a role in increasing the proficiency of the language among students (Awatif, Ku Fatahiyah, \& Hairun Najuwah, 2015).

Meanwhile, other than what was mentioned above, the fact that students associate learning with Culmulative Grade Point Average (CGPA) is also a factor worth mentioning. Their learning orientation is based on rewards in the form of increment in their CGPA (Ghazali, Nik Mohd Rahimi, \& Parilah, 2010). As a result, students would limit their learning simply to meet the grade they have set with full attention to what their lecturers delivered during the lectures and rely on the slides used throughout the learning process. This finding is reinforced by the fact that unstructured students rely solely on materials given to them in the classroom, therefore, make them to lack in self-initiative (Sanaoui, 1995). As such, the dependency of students on the lecturers is too high to the extent where they often request that the lecturers translate all expressions. This shows that most of them have no self-initiative while studying Arabic at public universities level.

Meanwhile, in a classroom situation, the student's engagement is at moderate level, which is shown by the ability to conduct presentation in front of the class and asking questions in Arabic to lecturers. Items used at this level are seen as part of the tasks that students are required to perform while in classroom at public universities. This situation shows that students have not yet used Arabic as a medium of communication widely among themselves. However, the classroom environment that uses communicative approaches (having to speak in front of the classroom, and asking questions) is seen to create discomfort among some students. This is because they are already too comfortable with teacher-centered learning, where all learning activities are set by lecturers without involving the students. Hence, some students see this change as a challenge and some consider it a threat (Baumfield, 2004). 
While in classroom, students at the public universities level are rarely in full Arabic speaking situations, such as speaking, listening to friends, speaking and discussing among themselves in Arabic. This is happening because of the fact that, there is only a slim probability to meet with friends who are passionate about interacting consistently in Arabic at all times and conditions. Additionally, this situation is often associated with the weakness of the student in the aspect of their speech. According to Nadwah and Nadhilah (2014), among the factors that prevent students from continuing to interact in Arabic are lack of vocabulary, language structure mistakes, low motivation and low self-confidence. The findings of this study is in line with the study of Nik Mohd Rahimi (1999) where it mentioned that the use of Arabic among university students is critical and at a level which one is not proud to mention. This is because only $5 \%$ usage in communicating were found during class while outside classroom was at $0 \%$.

\section{Outside Class}

The engagement of students in speaking Arabic with friends is seen to be at a high level of engagement among public universities students, especially when outside the classroom. The language learning among fellow students is said to have a positive impact on achievement (Lynch, 2006). This situation shows that students are more comfortable and tend to interact with each other in order to avoid a formal atmosphere (Zha, Kelly, Park, \& Fitzgerald, 2006).

The engagement of students in university activities and through print media (reading books) and electronic media (watching Arabic videos) is also expected to be the most favourite approach among students. However, research findings show otherwise that student engagement in such an activity is at a moderate level. This is supported by Ab. Ghani's (1993) statement, who mentioned that the opportunity for students to follow Arabic media is limited to reading books and listening to Arabic songs. This is because, the activity is an opportunity and a way for students to leverage and practice what they have learned during class. However, this finding shows that students are still trying to find an alternative outside of the classroom with Arabic reading materials, such as reading books, watching videos in Arabic and attending activities organised by the Arabic society even at moderate levels. This is supported by the study of Zawawi (2001), which reported that there are significant differences in co-curriculum activities conducted at IIUM and UKM. Hence, various activities need to be structured and planned by the authorities to enable students to strengthen and improve their language learning.

Although, Macis and Schmitt (2017) said that the engagement of students outside the classroom could help students in the process of acquiring language proficiency 
in the learning of foreign languages, but the findings show otherwise when almost $60 \%$ of the student's engagement in Arabic at the public universities level was low. This is supported by Ab. Halim (2009), who stated that the use of Arabic by public universities students outside the classroom, especially for Arabic students and Islamic studies was still low. The fact is, listening and speaking is the key to interaction and communication. As such, a good speaker is one who is able to make his/her listeners understand the words he speaks (Izuddin, 2008).

The lack of significant student engagements in Arabic outside the classroom may be due to the unwillingness of students to get involved in activity-related engagements (Arabic competitions) and social-related engagements (interacting with Arabic lecturers and native Arabic speakers from Arabic speaking nations). This is proven by Ab. Halim (2009), who found that students who have entered the institutions of higher learning did not practice Arabic speaking skills either during or outside classroom. This reluctances indicate that students at public universities level have negative attitudes, such as shyness, inferiority and fear of making mistakes. Thus, such weaknesses will eventually lead to the feeling of inferiority complex to speak and often comparing themselves with other friends (Ghazali et al., 2010). This situation often occurs among students, especially students in Malaysia (Alkusairy, 1998). Hence, such deficiency indicates that students at public universities level have negative attitudes (shyness and apparent low self-confidence).

The ability of students in listening skills is an advantage, especially to ensure the learning process is effective. Additionally, radio is said to be an authentic source of language learning. Although, this type of learning materials is easy to find and readily accessible, but the text in verbal form is categorised as quite difficult for students to understand (Musallam, 2007). It is not surprising if this study shows that the engagement of students with radio listening activities is rarely done by students in public universities. This is because, this study finding is similar to the research of Zawawi (2001), where it is found that activities such as radio listening received the lowest mean of Arabic usage among university students $(\mathrm{M}=1.42$, $\mathrm{SD}=0.53)$.

Besides, the difficulty in understanding messages arises because of the students' weaknesses in receiving and analysing the messages they hear. In addition, among other factors which contribute to the problem is due to the shortage of radio broadcasts in Malaysia that provide Arabic learning slots, such as Radio IKIM FM and Radio Malaysia Terengganu FM. Even so, the radio stations involved only allocate a few minutes of their airtime for Arabic sessions. According to Zawawi (2001), this lack of radio broadcast shows that students rarely listen to Arabicspeaking radio because the government is yet to create radio broadcasting station 
that uses the Arabic in Malaysia. The scenario is that, if a student wants to listen to foreign Arabic radio broadcast abroad, complication arises when students try to understand the formal (fushah) and informal (ammiyah) language which are mixed in its usage during such activity. The situation is further complicated by conversations that are too fast, thereby making it harder for students to understand. This difficulty therefore limits the student's interest in making radio listening activity as their daily routine and making it less attractive to them.

\section{CONCLUSION}

Overall, this study found that most public university students in actual fact use Arabic in real life. As such, activities that have been implemented by students are categorised as authentic in the context of Arabic learning. Therefore, this illustrates that the engagement of Arabic students at the university level is still moderate. Thus, this study suggested that the authorities need to put more initiative to improve this situation in order to support autonomous language learning among the students. Furthermore, in order to increase student engagement in the Arabic is to introduce more hands-on activities such as online quizzes, games, debates, and many more.

Accordingly, if students are required to learn Arabic in the environment where the language is not common and students need to follow limited learning period, they should utilise all language learning resources in the form of social, media and activities. This is because if students take advantage of all the facilities and opportunities available around them, indirectly the students will be able to support their Arabic learning. In accordance with recommendations of Kuh (2009), if students can maximise their engagement in the classroom as well as outside the classroom at the universities by focusing on media, social and activity attributes, this will indirectly contribute to the high achievement of students' language proficiency. Therefore, students should take advantage of opportunities they have by maximising engagement in the classroom and outside classroom at the university level. Consequently, this will contribute to high achievement in Arabic as well as to produce competent Arabic graduates. 


\section{REFERENCES}

Ab. Ghani Jalil. (1993). Masalah pengajaran dan pembelajaran bahasa Arab di Maktab Rendah Sains Mara (MRSM) Terendak. Unpublished Masters thesis, Universiti Kebangsaan Malaysia.

Ab. Halim Mohamad. (2009). Tahap komunikasi dalam bahasa Arab dalam kalangan pelajar sarjana muda bahasa Arab di IPTA Malaysia. Journal of Islamic and Arabic Education, 1(1), 1-14.

Ahmad Zaki Amiruddin, Ahmed Thalal Hassan, Ahmad Abdul Rahman, Nor Abdul Rahman, \& Mohd Shahriman Abu Bakar. (2017). Penggunaan Quizlet.com dalam proses pengajaran dan pembelajaran bahasa Arab. In Mohd Shahrizal Nasir et al. (Eds.), Penataran Pendidikan Bahasa Arab di Peringkat Pengajian Tinggi (pp. 71-92). Kuala Terengganu: Penerbit Universiti Sultan Zainal Abidin.

Al-Barashdi, H. S., Buoazza, A., \& Jabur, N. H. (2015). Smartphone addiction among university undergraduates: A literature review. Journal of Scientific Research \& Reports, 4(3), 210-225. https://doi.org/10.9734/JSRR/2015/12245

Al-Hasyimi, A. M. (2011). Madkhal Ta'lim al-Lughah wa ta'allumiha alQaim 'ala alMahammah: Ususuhu al- Nazariyah wa al- tatbiqiyah. In Qadaya ta'lim allughah al-arabiyah wa ta'allumiha. Gombak: IIUM Press.

Alkusairy, M. A. (1998). Pendekatan komunikatif bagi pengajaran bahasa Arab sebagai bahasa asing. In Juriah Long (Ed.), Inovasi dalam perkaedahan pengajaran bahasa, sains sosial dan teknologi maklumat (pp. 126-140). Bangi: Penerbit Universiti Kebangsaan Malaysia.

Allwright, R. L. (1984). The importance of interaction in classroom language learning. Applied Linguistics, 5(2), 156-171. https://doi.org/10.1093/applin/5.2.156

Awatif Abd Rahman, Ku Fatahiyah Ku Azizan, \& Hairun Najuwah Jamali. (2015). Persepsi pelajar di IPT Malaysia terhadap pengajaran dan pembelajaran bahasa Arab. Retrieved from https://ejurnalfp.files.wordpress.com/2015/08/persepsipelajar-di-ipt-malaysia-terhadap-pengajaran-dan-pembelajaran-bahasa-arab.pdf

Baumfield, V. (2004). Thinking for yourself and thinking together: The community of inquiry as a pedaagogy for self-regulated learning. In J. Ee, A. Chang, \& O. S. Tan (Eds.), Thinking about thinking: What educators need to know (pp. 72-87). Singapore: McGraw Hill.

Brown, H. D. (1994). Principles of language learning and teaching. The Modern Language Journal, 72(1), 69. https://doi.org/10.2307/327571

Brown, H. D. (2000). Principles of language learning and teaching. Language, 57(3), 781782. https://doi.org/10.2307/414380

Chen, P., Lambert, A., \& Guidry, K. (2010). Engaging online learners: The impact of web-based learning technology on college student engagement. Computers \& Education, 54(5), 1222-1232. https://doi.org/10.1016/j.compedu.2009.11.008

Ellis, N. C. (2005). Implicit and explicit language learning their dynamic interface and complexity. Studies in Second Language Acquisition, 27(2), 305-352. https://doi .org/10.1017/S027226310505014X 
Fariza Khalid, Md Yusoff Daud, \& Mohd Khalid Mohamad Nasir. (2016). Perbandingan penggunaan telefon pintar untuk tujuan umum dan pembelajaran dalam kalangan pelajar universiti. International Conference on Education and Regional Development 2016 (ICERD 2016), International Conference on Education and Regional Development 2016 (ICERD 2016), Bandung, Indonesia, 31 October1 November.

Fernandez, B. G., \& Schmitt, N. (2015). How much collocation knowledge do L2 learners have? The effects of frequency and amount of exposure. International Journal of Applied Linguistics, 1(2015), 94-126. https://doi.org/10.1075/itl.166.1.03fer

Ghazali Darusalam, \& Sufean Hussin. (2016). Metodologi penyelidikan dalam pendidikan. Kuala Lumpur: Penerbit Universiti Malaya.

Ghazali Yusri, Nik Mohd Rahimi, \& Parilah M. Shah. (2010). Sikap pelajar terhadap pembelajaran kemahiran lisan Bahasa Arab di Universiti Teknologi MARA (UiTM). GEMA Online Journal of Language Studies, 10(3), 15-33.

Ghazali Yusri, Nik Mohd Rahimi, Parilah M. Shah, Wan Haslina Wah, \& Muhammad Sabri Sahrir. (2012). Penggunaan Bahasa Arab lisan dan hubungannya dengan strategi pengurusan sumber. GEMA Online Journal of Language Studies, 12(2), 505-520.

Izuddin Muhammed. (2008). Meningkatkan proses pengajaran dan pembelajaran Bahasa Arab dalam bilik darjah melalui penggunaan Lughatul Fasli: Satu tinjauan awal. Paper presented at Prosiding Persidangan Kebangsaan Bahasa Arab (NCAL2015), Bangi, Institut Pendidikan Guru Pendidikan Islam, Bangi, 18-19 August 2015.

Kamarulzaman Abdul Ghani, Zawawi Ismail, \& Nik Mohd Rahimi Nik Yusoff. (2001). Peranan persekitaran bahasa Arab terhadap bahasa Arab Komunikasi. Paper presented at Prosiding Wacana Pendidikan Islam (Siri 1), Kolej Islam Selangor Darul Ehsan, 16 July. pp. 254-263.

Keefe, J. W. (1991). Learning style: Cognitive and thinking skills. Reston, VA: National Association of Secondary School Principles.

Kuh, G. D. (2009). The national survey of student engagement: Conceptual and empirical foundations. New Directions for Instittutional Research, 14(7), 1-11. https://doi .org/10.1002/ir.283

Littlewood, W. (1981). Communicative language teaching: An introduction. Cambridge: Cambridge Language Teaching Library.

Lynch, D. J. (2006). Motivational factors, learning strategies and resource management as predictors of course grades. College Student Journal, 40(2), 423-428.

Macis, M., \& Schmitt, N. (2017). Not just 'small potatoes': Knowledge of the idiomatic meanings of collocation. Language Teaching Research, 21(3), 321-340. https:// doi.org/10.1177/1362168816645957

Madkur, A. A. (1987). Nahj Tarbiyah Islamiyah: Usuluhu wa Tatbiqatuhu. Kuwayt: Maktabah Fallah.

Maimun Aqsha Lubis. (1997). Satu perbandingan kesan tiga kaedah pengajaran Bahasa Arab terhadap pencapaian kemahiran bahasa di Pusat Matrikulasi Universiti Islam Antarabangsa. Bangi: Universiti Kebangsaan Malaysia. 
Mohd Firdaus Yahaya. (2012). Istikhdam al-burtfuliyu al-ilikturniy lada al-talabah almutakhassisin fi al-Lughah al-'Arabiyah: Tatwir wa tanfaz watqwim. Unpublished Master's thesis, Universiti Islam Antarabangsa Malaysia.

Mohd Firdaus Yahaya, Muhammad Sabri Sahrir, \& Mohd Shahrizal Nasir. (2013). Pembangunan laman web EZ-Arabic sebagai alternatif pembelajaran maya Bahasa Arab bagi pelajar sekolah rendah Malaysia. Jurnal Teknologi (Sains dan Kejuteraan), 1(7), 11-18.

Muhammad Saiful Anuar Yusoff, Muhammad Luqman Ibnul Hakim Mohd Saad, Shahrizal Mahpol, \& Zawiah Seman. (2017). Motivasi membaca buku teks sastera Arab di kalangan pelajar STAM di Kelantan. Paper presented at Seminar Kebangsaan Bahasa dan Kesusteraan Arab 2017, UniSZA, 28 October.

Musallam, A. (2007). Using authentic materials in a foreign language classroom: Teachers' perspectives in Saudi Arabia. (Online serial) 22(528). Retrieved from http://faculty.ksu.edu.sa/enasalmusallam/default.aspx.

Nadwah Daud, \& Nadhilah Abdul Pisal. (2014). Permasalahan pertuturan dalam Bahasa Arab sebagai bahasa kedua (Speaking problems in Arabic as a second language). GEMA Online Journal of Language Studies, 14(February), 117-133. https://doi .org/10.17576/GEMA-2014-1401-08

Nik Mohd Rahimi Nik Yusoff. (1999). Bahasa Arab untuk kemahiran komunikasi: Satu kajian tentang pelaksanaanya dan cabaran pengajaran dan pembelajaran di abad ke-21. Paper presented at Prosiding Seminar Isu-Isu Pendidikan Negara, Universiti Kebangsaan Malaysia, 26-27 November, pp. 226-236.

Noresah Baharom. (2005). Kamus dewan edisi keempat. Kuala Lumpur: Dewan Bahasa dan Pustaka.

Norhayati Che Hat, Shaferul Hafes Sha'ari, \& Mohd Fauzi Abdul Hamid. (2013). Persepsi pelajar terhadap penggunaan animasi dalam pembelajaran. Jurnal Teknologi (Social Sciences), 63(1), 25-29. https://doi.org/10.11113/jt.v63.1683

Oxford, R. L. (1990). Language learning strategies: What every teacher should know. New York: Newbury House Publisher.

Philp, J., \& Duchesne, S. (2016). Exploring engagement in tasks in the language classroom. Annual Review of Applied Linguistics, 36, 50-72. https://doi.org/10.1017/ S0267190515000094

Richards, J., \& Rodgers, T. (2001). Approaches and methods in language leaching. New York: Cambridge University Press. https://doi.org/10.1017/CBO9780511667305

Rosni Samah. (2011). Isu pembelajaran Bahasa Arab. Persidangan Kebangsaan Pengajaran Dan Pembelajaran Bahasa Arab 2012 (PKEBAR'12), Port Dickson, Negeri Sembilan, 19 May 2012.

Rost, M. (2002). Teaching and researching listening. London: Longman. https://doi .org/10.1017/CBO9780511667206.002

Sanaoui, R. (1995). Adults leaners' approaches to learning vocabulary in second languages. Modern Language Journal, 79, 15-28. https://doi.org/10.1111/j.1540-4781.1995. tb05410.x 
Schmitt, N., \& Redwood, S. (2011). Learner knowledge of phrasal verbs: A coprus -informed study. In F. Meunier, S. De Cock, G. Gilquin, \& M. Paquot (Eds.), $A$ taste for corpora: In honour of Sylviane Granger, (pp. 173-208). Amsterdam: John Benjamins Publishing Company. https://doi.org/10.1075/scl.45.12sch

Skinner, E. A., \& Pitzer, J. R. (2012). Developmental dynamics of student engagement, coping, and everyday resilience. Handbook of Research on Student Engage, 7, 515-539. https://doi.org/10.1007/978-1-4614-2018-7

Sohana Abdul Hamid. (2016). Pengaruh media massa terhadap perubahan sosial masyarakat. Journal of Social Sciences And Humanities, 1(Special Issue), 214-226.

Tu'aymah, R. A. (2004). Al maharat al lughawiyyah: Mustawiyatuha, tadrisuha, so'ubatuha. Kaherah: Dar al-Fikr al-Arabi.

Zawawi Ismail. (2001). Hubungan antara persekitaran bahasa Arab dengan kemahiran bertutur dalam bahasa Arab di kalangan pelajar universiti di Malaysia. Unpublished Master's thesis, Universiti Kebangsaan Malaysia.

Zha, S., Kelly, P., Park, M. A. K., \& Fitzgerald, G. (2006). An investigation of communicative competence of ESL students using electronic discussion board. Journal of Research on Technology in Education, 38(3), 349-367. https://doi.org /10.1080/15391523.2006.10782464 